This document was prepared in conjunction with work accomplished under Contract No. DE-AC09-96SR18500 with the U.S. Department of Energy.

This work was prepared under an agreement with and funded by the U.S. Government. Neither the U. S. Government or its employees, nor any of its contractors, subcontractors or their employees, makes any express or implied: 1 . warranty or assumes any legal liability for the accuracy, completeness, or for the use or results of such use of any information, product, or process disclosed; or 2 . representation that such use or results of such use would not infringe privately owned rights; or 3 . endorsement or recommendation of any specifically identified commercial product, process, or service. Any views and opinions of authors expressed in this work do not necessarily state or reflect those of the United States Government, or its contractors, or subcontractors. 
WSRC-STI-2008-00369

\title{
NETEC COLD CRUCIBLE INDUCTION MELTER DEMONSTRATION FOR SRNL WITH SIMULATED SLUDGE BATCH 4 DWPF WASTE
}

\author{
Michael E. Smith, Allan B. Barnes, Alex S. Choi, and James C. Marra \\ Washington Savannah River Company \\ Aiken, SC, USA
}

\begin{abstract}
Cold Crucible Induction Melter (CCIM) Technology is being considered as a possible next generation melter for the Defense Waste Processing Facility (DWPF). Initial and baseline demonstrations that vitrified a Sludge Batch 4 (SB4) simulant at a waste loading of 50 weight percent (versus about 38 weight percent in the current DWPF Melter) were performed by the Nuclear Engineering and Technology Institute (NETEC) in South Korea via a subcontract from the Washington Savannah River Company (WSRC). This higher waste loading was achieved by using a CCIM which can run at higher glass processing temperatures $\left(1250^{\circ} \mathrm{C}\right.$ and higher $)$ than the current DWPF Melter $\left(1150^{\circ} \mathrm{C}\right)$. Higher waste loadings would result in less canisters being filled and faster waste throughput at the DWPF. The main demonstration objectives were to determine the maximum melt rate/waste throughput for the NETEC CCIM with a Sludge Batch 4 simulant as well as determine the viability of this technology for use in the DWPF.
\end{abstract}

\section{INTRODUCTION}

The Cold Crucible Induction Melter (CCIM) offers several advantages over the ceramic-lined, Joule-heated melter currently used in the Defense Waste Processing Facility (DWPF). These advantages include; 1) increased waste loading (WL) of 50+ weight percent versus 34 to 38 weight percent, thus resulting in less glass canisters produced, therefore reducing the lifecycle costs for canister production and storage, 2) possible extended melter service life, 3 ) higher waste throughput with a smaller footprint and lower costs, and 4) higher tolerance for troublesome metals (aluminum and noble metals).

Due to the above potential benefits, Washington Savannah River Company (WSRC) awarded a contract (funded by DOE-EM 20) to the Nuclear Engineering and Technology Institute (NETEC) to perform two pilot-scale $(550 \mathrm{~mm}$ diameter) CCIM demonstrations of up to 72 hours each at the NETEC facility in South Korea. Unlike other CCIM's which use an agitator to help increase the melt rate, the NETEC CCIM uses 12 bubblers. The NETEC demonstrations were performed with simulated Savannah River Site (SRS) High Level Waste (HLW) Sludge Batch 4 (SB4) slurry feed at a waste loading of 50 weight percent and a melt pool temperature of $1250^{\circ} \mathrm{C}$. The main objectives of the demonstrations were to enable WSRC to: 1) determine the viability of the CCIM technology for use with SRS HLW slurry feed in the DWPF, 2) aid in determining the required CCIM sizing for application at the DWPF to achieve the desired melt rate/waste throughput, and 3) establish additional information needed for future CCIM testing and project planning.

The initial and baseline demonstrations were performed in October and November, 2007, respectively. WSRC personnel witnessed the baseline demonstration. The purpose of the initial demonstration was to access, and optimize where necessary, the electrical parameters during operation of the CCIM, the nominal operating conditions, the general behavior of the system, and to identify any off-normal or operational anomalies (if any) encountered during this initial demonstration. Based on findings from the initial demonstration, the purpose of the 
baseline demonstration was to acquire process data that would support sizing of a CCIM that could be deployed in the DWPF (primarily melt rate flux and glass waste loading).

\section{CCIM TECHNOLOGY}

This section gives a general description of CCIM technology, as well as details of the NETEC CCIM equipment. Electromagnetic induction is applied into the CCIM by placing a conductor such as molten glass in a variable magnetic field. As shown in Figure 1, an AC potential difference is applied to the inductor. This creates a variable magnetic field both inside and outside of the inductor. If the electrically conductive glass melt is placed inside of the inductor, the variation in the magnetic field causes a change in the magnetic flux passing through the glass melt. Per Lenz's law, this induces an electromotive force (EMF) which causes induced currents. These induced currents in the glass are converted into heat due to the Joule effect in the glass melt. ${ }^{1,2}$

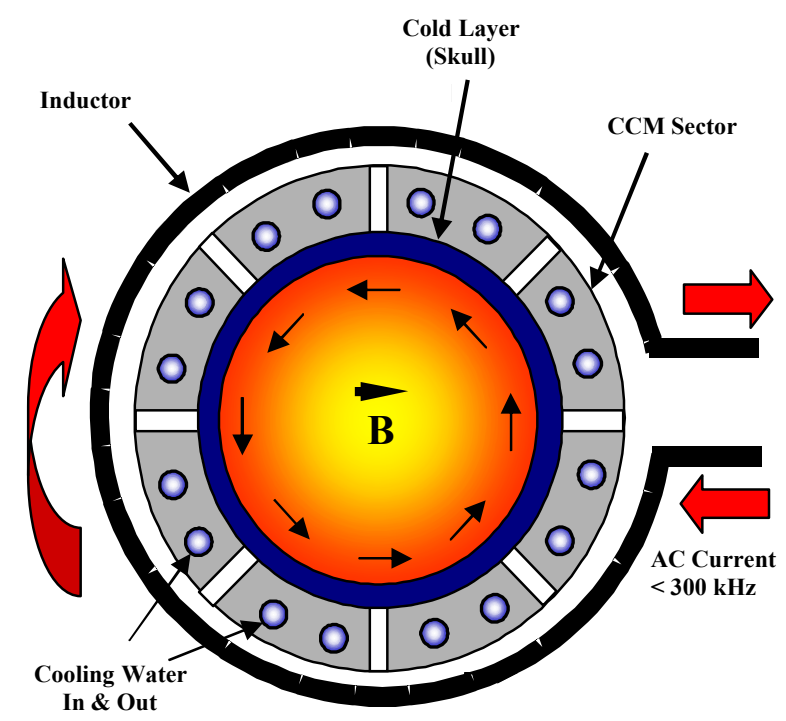

Figure 1. Sketch of CCIM Showing Application of Induction Heating

As shown in Figure 2, the CCIM is a simple and robust structure made of plain stainless steel and cooled by water. The electromagnetic field penetrates into the CCIM through the gaps between the stainless sectors (see Figure 1). For startup purposes, the CCIM is designed to inductively heat an electrically conductive susceptor that in turn oxidizes and heats the glass in the crucible. The molten glass is then directly heated while the crucible is water cooled. This cooling causes a thin layer of solidified glass (skull) to coat the inside surface of the crucible, thereby protecting it from the corrosive melt. Since the energy source is outside of the melter, electrode corrosion is avoided.

In addition to increasing the melter lifetime, this technology allows for much higher operating glass temperatures $\left(>1500^{\circ} \mathrm{C}\right)$ than conventional melters with either Inconel or molybdenum electrodes. The glass melt is batch poured through a cooled bottom drain valve as shown in Figure 2. Twelve bubblers are symmetrically located at the bottom of the CCIM to increase glass convection and thereby insure glass homogeneity and higher melt rates. Feed is delivered into the CCIM and the resultant off-gas is treated by an off-gas system that includes a High Temperature Filter (HTF), HEPA Filter, Post Combustion Chamber, Off-Gas Cooler, Scrubber, Reheater A, Activated Carbon/HEPA Filter, Blower, Reheater B, and DeNOx System. 


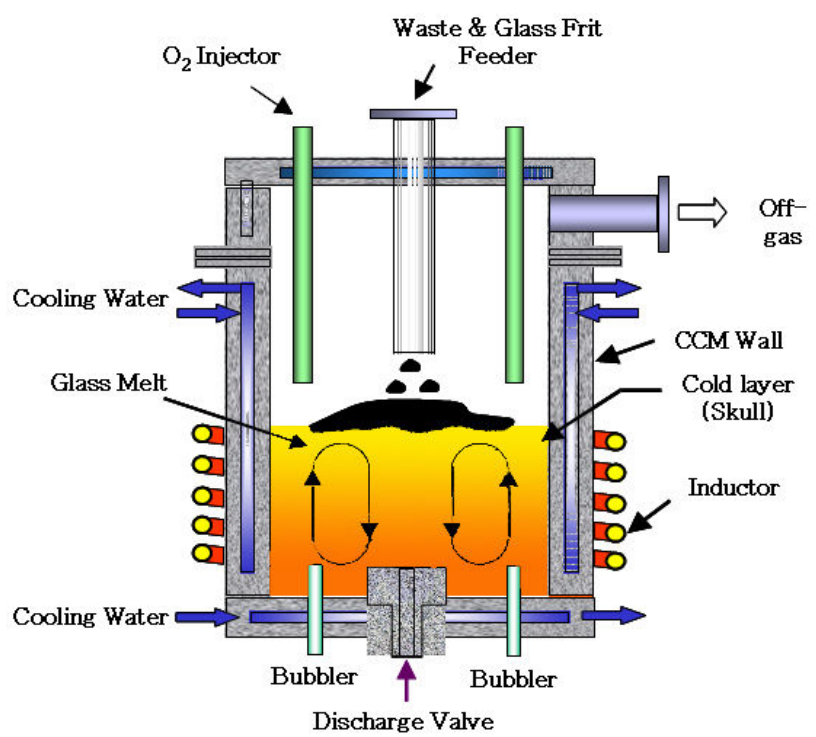

Figure 2. Cross-Section View of NETEC CCIM

\section{FEED AND STARTUP GLASS DETAILS}

The non-radioactive simulant used for the demonstrations was the SRS HLW SB4 which contains a high level of aluminum. The targeted and analyzed compositions of this simulant (dried and calcined at $900^{\circ} \mathrm{C}$ ) are given below in Table I.

Table I. Compositions of Dried and Calcined SB4 Simulant Sludge

\begin{tabular}{|c|c|c|c|c|}
\hline \multirow{2}{*}{ Element } & \multicolumn{2}{|c|}{ Dried Sludge } & \multicolumn{2}{c|}{ Calcined Sludge } \\
\cline { 2 - 5 } & Target Wt. \% & Analyzed Wt. \% & Target Wt. \% & Analyzed Wt. \% \\
\hline $\mathrm{Al}$ & 10.433 & 11.80 & 14.904 & 14.40 \\
\hline $\mathrm{Ca}$ & 1.528 & 1.68 & 2.183 & 1.18 \\
\hline $\mathrm{Cr}$ & 0.105 & 0.03 & 0.150 & 0.11 \\
\hline $\mathrm{Cu}$ & 0.032 & 0.03 & 0.045 & 0.03 \\
\hline $\mathrm{Fe}$ & 15.680 & 15.5 & 22.40 & 17.7 \\
\hline $\mathrm{K}$ & 0.044 & 0.24 & 0.06 & 0.33 \\
\hline $\mathrm{Mg}$ & 1.293 & 1.53 & 1.848 & 0.22 \\
\hline $\mathrm{Mn}$ & 3.464 & 3.11 & 4.948 & 3.52 \\
\hline $\mathrm{Na}$ & 10.732 & 12.4 & 15.332 & 20.30 \\
\hline $\mathrm{Ni}$ & 1.009 & 1.03 & 1.441 & 1.20 \\
\hline $\mathrm{S}$ & 0.224 & 0.08 & 0.320 & 0.20 \\
\hline $\mathrm{Si}$ & 0.980 & 1.01 & 1.40 & 1.12 \\
\hline $\mathrm{Zn}$ & 0.031 & 0.03 & 0.044 & 0.04 \\
\hline $\mathrm{Zr}$ & 0.052 & 0.05 & 0.074 & 0.06 \\
\hline
\end{tabular}

The SB4 analyses show that the targeted weight percents of the major elements were met with the exception of sodium, which was higher than targeted. The impact of this high sodium content on the glass will be discussed later. The sludge slurry (about 32.64 weight percent sludge and the remainder water) was mixed with glass Frit 503-R3 to target a waste loading of $50 \%$ on a calcined solids basis. No reductant such as formic acid (used in the current DWPF 
feed preparation process) was added to the feed. This should result in highly oxidized feed and glass product. For reference, 10 liters of slurry should produce about $5.65 \mathrm{~kg}$ of glass. For the initial startup, startup glass SB4-503-R3 was placed in the CCIM. The composition of the SB4503-R3 startup glass targets the composition of the SB4 sludge mixed with Frit 503-R3 at 50 weight percent waste loading. The targeted and analyzed compositions of the startup glass SB4503-R3 and the glass Frit 503-R3 are given in Table II.

Table II. Compositions of Startup Glass SB4-503-R3 and Glass Frit 503-R3

\begin{tabular}{|c|c|c|c|c|}
\hline \multirow[b]{2}{*}{ Oxide } & \multicolumn{2}{|c|}{ SB4-503-R3 Startup Glass } & \multicolumn{2}{|c|}{ Glass Frit 503-R3 } \\
\hline & $\begin{array}{l}\text { Target } \\
\mathrm{Wt} \%\end{array}$ & $\begin{array}{c}\text { Analyzed } \\
\mathrm{Wt} \%\end{array}$ & $\begin{array}{l}\text { Target } \\
\mathrm{Wt} \%\end{array}$ & $\begin{array}{c}\text { Analyzed } \\
\mathrm{Wt} \%\end{array}$ \\
\hline $\mathrm{Al}_{2} \mathrm{O}_{3}$ & 14.14 & 14.90 & - & - \\
\hline $\mathrm{B}_{2} \mathrm{O}_{3}$ & 8.00 & 10.60 & 16.00 & 18.00 \\
\hline $\mathrm{CaO}$ & 1.53 & 1.53 & - & - \\
\hline $\mathrm{Ce}_{2} \mathrm{O}_{3}$ & 0.12 & 0.06 & - & - \\
\hline $\mathrm{Cr}_{2} \mathrm{O}_{3}$ & 0.11 & 0.11 & - & - \\
\hline $\mathrm{Fe}_{2} \mathrm{O}_{3}$ & 16.08 & 17.20 & - & - \\
\hline $\mathrm{Li}_{2} \mathrm{O}$ & 4.00 & 3.75 & 8.00 & 7.88 \\
\hline $\mathrm{MgO}$ & 1.54 & 1.11 & - & - \\
\hline $\mathrm{MnO}_{2}$ & 3.21 & 1.45 & - & - \\
\hline $\mathrm{Na}_{2} \mathrm{O}$ & 11.37 & 10.40 & 2.00 & 1.67 \\
\hline $\mathrm{NiO}$ & 0.92 & 0.78 & - & - \\
\hline $\mathrm{SO}_{3}$ & 0.48 & 0.40 & - & - \\
\hline $\mathrm{SiO}_{2}$ & 38.50 & 38.70 & 74.00 & 73.90 \\
\hline
\end{tabular}

The viscosity and electrical conductivity of the SB4-503-R3 startup glass were estimated using the computer code GlassForm v.1.1 to be about 50 poise and $0.45 \mathrm{~S} / \mathrm{cm}$, respectively, at $1,250^{\circ} \mathrm{C}$. Both of these properties were deemed acceptable by NETEC.

\section{INITIAL STARTUP}

To start up the CCIM for the initial demonstration, $50 \mathrm{~kg}$ of the SB4-503-R3 startup glass was first added. A quarter-cut titanium ring ( 40 grams) was next loaded on top of the startup glass and then an additional $20 \mathrm{~kg}$ of startup glass was loaded on top of the ring. The High Frequency Generator (HFG) was started at $30 \mathrm{KW}$ and incrementally increased by $10 \mathrm{KW}$ per minute up to $80 \mathrm{KW}$. After that increases to the $\mathrm{HFG}$ of $5 \mathrm{KW} / 30$ seconds were performed to achieve the targeted glass temperature of $1250^{\circ} \mathrm{C}$. The nominal frequency for the HFG is 300 $\mathrm{KHz}$ and it can provide up $400 \mathrm{KW}$ of power. Figure 3 shows the titanium ring with glass melting around it during the initial startup. 


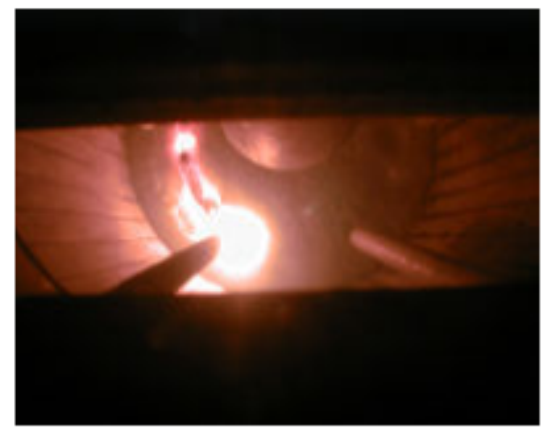

(a) Ignition of Ti Ring

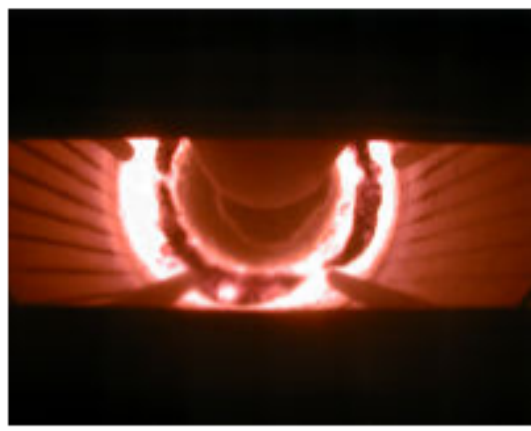

(b) Completion of Ignition

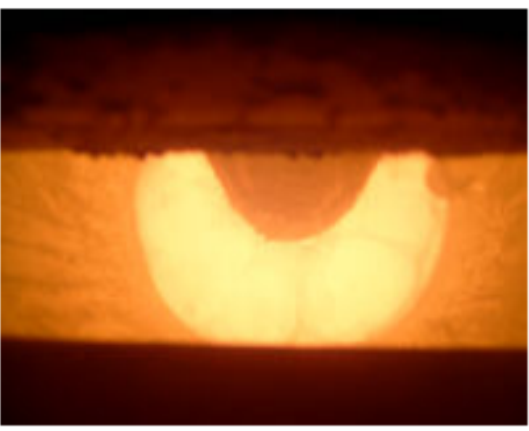

(c) Preparation of Glass Melt

Figure 3. Initial Melting of Glass in CCIM Using a Titanium Susceptor

\section{INITIAL AND BASELINE DEMONSTRATION DETAILS}

The initial demonstration was started on 10/17/07 and finished on 10/19/07. The melter startup took only 1.5 hours to reach $1250^{\circ} \mathrm{C}$. The $\mathrm{HFG}$ power was then increased to $240 \mathrm{KW}$ to thoroughly mix the glass melt at $1350^{\circ} \mathrm{C}$ for a few minutes. The $\mathrm{HFG}$ power was then reduced to $200 \mathrm{KW}$ to maintain a glass temperature of $1250^{\circ} \mathrm{C}$.

The feed rate was started at 15 liters/hour and then incrementally increased to as high as 50 liters/hour. Pouring was done in a batch mode versus continuous pouring. From 15 to 30 liters/hour, the cold cap coverage was about 60 percent or less. Figure 4 gives a series of pictures of the cold cap at various feed rates. At 50 liters/hour, the cold cap coverage was about 80 percent. Unfortunately, the pressure drop in the off-gas HTF began to increase such that the demonstration had to be ended. The melter performance was deemed acceptable, including the various melter parameters being monitored.
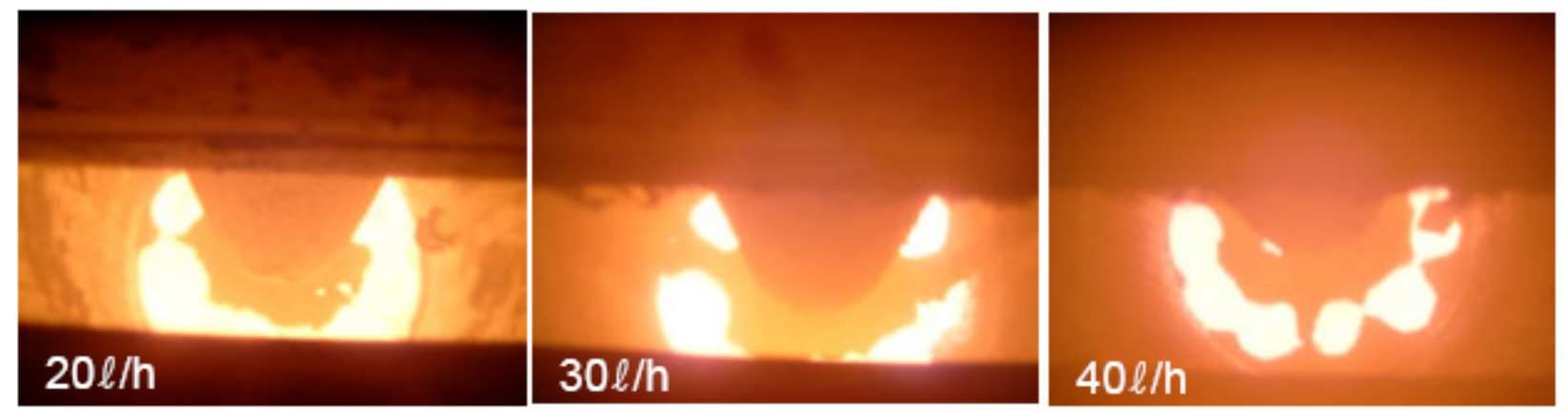

Figure 4. Photographs of Cold Cap at Various Feed Rates

The baseline demonstration was started on $11 / 27 / 07$ and completed on 11/30/07. The heatup of the CCIM was performed the same as for the initial demonstration. The CCIM feed was doped with nonradioactive cesium (fed as $\mathrm{CsNO}_{3}$ ) to target a 0.5 weight percent $\mathrm{Cs}_{2} \mathrm{O}$ concentration in the glass to determine a rough estimate of cesium volatility in the CCIM. The CCIM was fed at 40 liters/hour for about 70.5 hours of steady operation. The feed rate was then increased to 50 liters/hour for about 50 minutes without any issues. After this, the feed rate was increased to 60 liters/hour for about 30 minutes. Some irregularities were noticed in the cold cap, but vent holes were still present in the cold cap. At this time the test was ended after 72 hours of feeding. As with the initial demonstration, pouring was performed in a batch mode for the baseline demonstration. 
As the demonstration progressed, it became a little more difficult to pour the glass via the bottom pour discharge valve. The reason for this was believed to be that glass in the drain valve had crystallized to some extent. Overall, the performance of the CCIM was deemed to be acceptable. Figure 5 shows the profiles of the CCIM electrical parameters and glass temperatures during the baseline demonstration. The two higher glass temperatures on the plot (about $1250^{\circ} \mathrm{C}$ ) are those from the thermocouples located at heights of 8 and $12 \mathrm{~cm}$. The lower temperature (less than $400^{\circ} \mathrm{C}$ ) are those from a thermocouple located $4 \mathrm{~cm}$ above the bottom of the CCIM. This lower temperature is due to the close proximity of the water cooled melter floor.

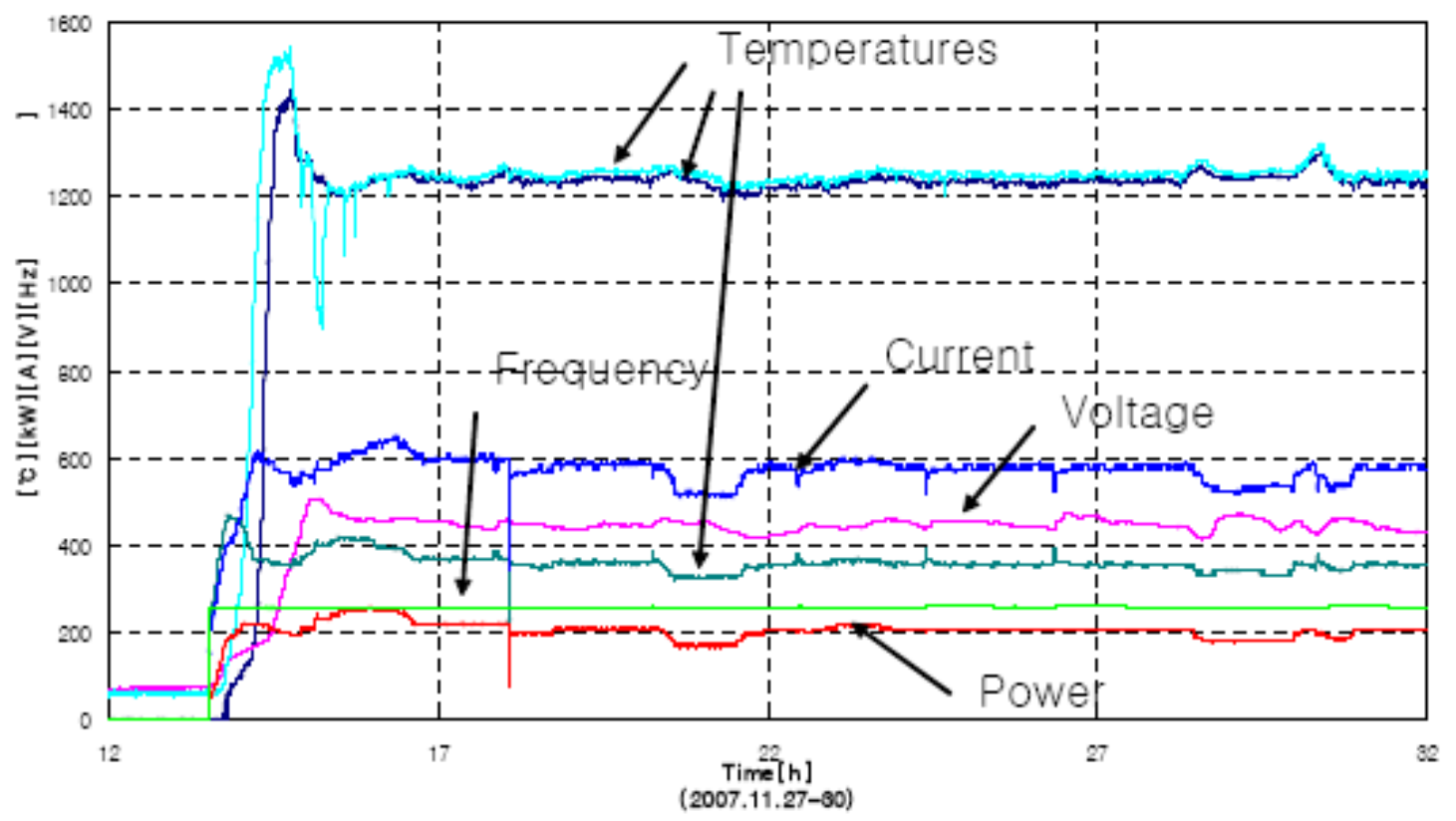

Figure 5. CCIM Melter Electrical Parameters and Temperatures during Baseline Demonstration

\section{DISCUSSION OF BASELINE DEMONSTRATION RESULTS}

Melt Rate and Waste Throughput

Table III summarizes the maximum feed rate, melt rate, waste throughput (WT), melt flux, and WT flux determined in the baseline demonstration at a waste loading of about 50 percent. The melt surface areas of the DWPF Melter and the $550 \mathrm{~mm}$ CCIM are $28.3 \mathrm{ft}^{2}\left(2.63 \mathrm{~m}^{2}\right)$ and $2.557 \mathrm{ft}^{2}\left(0.2376 \mathrm{~m}^{2}\right)$, respectively. It is noted that the calculated melt flux of the CCIM at $1,250{ }^{\circ} \mathrm{C}$ is 3 times higher than that of the DWPF melter design basis at $1,150{ }^{\circ} \mathrm{C}$ despite having an order of magnitude smaller melt surface area.

Table III. Summary of Maximum Rates Determined in NETEC CCIM Baseline Demonstration

\begin{tabular}{|c|c|c|c|c|c|}
\hline $\begin{array}{c}\text { Melt } \\
\text { Temp } \\
\left({ }^{\circ} \mathrm{C}\right)\end{array}$ & $\begin{array}{c}\text { Max. Feed } \\
\text { Rate } \\
\text { gal/hr }(\mathrm{l} / \mathrm{hr})\end{array}$ & $\begin{array}{c}\text { Max. Melt } \\
\text { Rate } \\
\mathrm{lb} / \mathrm{hr}(\mathrm{kg} / \mathrm{hr})\end{array}$ & $\begin{array}{c}\text { Max. WT } \\
\mathrm{lb} / \mathrm{hr} \\
(\mathrm{kg} / \mathrm{hr})\end{array}$ & $\begin{array}{c}\text { Max. Melt } \\
\text { Flux } \\
\mathrm{lb} / \mathrm{hr}^{2} / \mathrm{ft}^{2} \\
\left(\mathrm{~kg} / \mathrm{hr}^{2} \mathrm{~m}^{2}\right)\end{array}$ & $\begin{array}{c}\text { Max. WT } \\
\begin{array}{c}\text { Flux } \\
\mathrm{lb} / \mathrm{hr}^{2} / \mathrm{ft}^{2} \\
\left(\mathrm{~kg} / \mathrm{hr}^{2} / \mathrm{m}^{2}\right)\end{array}\end{array}$ \\
\hline 1250 & 13.2 & 62.4 & 31.3 & 24.4 & 12.2 \\
& $(50)$ & $(28.3)$ & $(14.2)$ & $(119.6)$ & $(59.8)$ \\
\hline
\end{tabular}




\section{Estimated Rates for 1.1m CCIM for DWPF}

The required scale-up from a pilot 550mm CCIM to a larger CCIM that would potentially be installed in the DWPF is unknown, especially since this technology (bubblers, induction heating) is much different than the DWPF melter. However, if one assumes that the melt flux would be the same for a larger CCIM, an estimate of the melt rate and waste throughput for this particular feed can be made. If a CCIM with a diameter of $1.1 \mathrm{~m}(3.609 \mathrm{ft})$ is used (per estimates by the NETEC staff), then for the same SB4 simulant feed processed in these demonstrations, the estimated melt rates and waste throughputs for this larger CCIM would be as given below in Table IV. The estimated waste throughput would therefore be about twice that of the existing DWPF melter. However, this is data from just one demonstration with one simulated feed. Still, the results are promising with regards to melt rate and waste throughput.

Table IV. Comparison of Estimated Maximum Melt Rate and WT for a 1.1m NETEC CCIM using Baseline Demonstration SB4 Simulant Feed.*

\begin{tabular}{|c|c|c|}
\hline Melt Temp $\left({ }^{\circ} \mathrm{C}\right)$ & $\begin{array}{c}\text { Max. Melt Rate } \\
\mathrm{lb} / \mathrm{hr}(\mathrm{kg} / \mathrm{hr})\end{array}$ & $\begin{array}{c}\text { Max. WT } \\
\mathrm{lb} / \mathrm{hr}(\mathrm{kg} / \mathrm{hr})\end{array}$ \\
\hline 1250 & $245.2(111.2)$ & $122.6(55.6)$ \\
\hline
\end{tabular}

* For the SB4/Frit 510 feed, the highest melt rate and waste throughput of the DWPF melter at 35\% WL are about $175 \mathrm{lb} / \mathrm{hr}(79.4 \mathrm{~kg} / \mathrm{hr})$ and $61 \mathrm{lb} / \mathrm{hr}(27.7 \mathrm{~kg} / \mathrm{hr})$, respectively.

\section{Demonstration Glass Properties}

The Savannah River National Laboratory (SRNL), part of WSRC, ran elemental analyses on the six glass pour samples from the baseline demonstration, and a review of the results was performed by the NETEC and SRNL personnel. It was determined that the measured glass composition was close to target with the exception of higher than expected $\mathrm{Na}_{2} \mathrm{O}$ values (about 15 weight percent versus a target of 11.31 ). The higher than targeted $\mathrm{Na}_{2} \mathrm{O}$ values were probably due to insufficient sludge washing. NETEC made the sludge per instructions fro $\mathrm{m}$ SRNL. Higher sodium in the feed can increase the amount of nepheline $\left(\mathrm{NaAlSiO}_{4}\right)$ crystals that are formed in the glass product. Nepheline is known to negatively impact glass durability. ${ }^{3}$

Per analysis of these same six samples, the glasses were found to be all fully oxidized with the exception of the sample taken from the pour made at the end of the demonstration (72 hours into the demonstration). Even this sample was almost fully oxidized with a $\mathrm{Fe}^{2+} / \Sigma \mathrm{Fe}^{\text {total }}$ ratio of 0.05 (where 0 is fully oxidized and the current DWPF target is approximately 0.20). These values agree with the fact that no reductant such as formic acid was used in the preparation of the feed for these demonstrations. This was the probable cause for foaming noted in the CCIM when the glass temperature was increased from $1250^{\circ} \mathrm{C}$ to $1350^{\circ} \mathrm{C}$ at the end of the initial demonstration as previously noted.

Samples from the same six glass pours during the baseline demonstration were submitted to SRNL for the Product Consistency Test (PCT) analysis. The PCT is used to determine the durability of waste glasses. A portion of each pour sample was also subjected to the modified Canister Centerline Cooling (CCC) thermal treatment before being subjected to the PCT. This modified CCC treatment is based on an estimate of the cool down rate of glass in the centerline of a DWPF canister filled at DWPF pour rates with a melt pool temperature of $1250^{\circ} \mathrm{C}$ (versus $1150^{\circ} \mathrm{C}$ for the current DWPF melter). It should be noted that the actual glass cool down rate of glass processed in a CCIM using batch pouring (versus the current DWPF mode of continuous pouring) had not been determined. A summary of the results is given in Table V. In the glass 
sample ID's, xxHR denotes the hour in which the pour sample was taken during the baseline demonstration. CCC indicates that the pour sample was submitted to the modified CCC thermal treatment prior to the PCT analysis. This thermal treatment increases the chance of crystal formation in the glass. EA glass is the HLW Environmental Assessment glass. The EA glass is the benchmark that DWPF glass must meet to be acceptable for repository disposal. The results showed that all of the quenched ("as is") glasses were more durable than the EA standard by about an order of magnitude. However, four of the six CCC thermal treated glasses failed the PCT test as they were less durable than the EA benchmark.

Table V. Summary of PCT Results (Average Normalized Release in Gram Glass/Liter Leachant)

\begin{tabular}{|c|c|c|c|c|}
\hline Glass Sample ID & $\mathrm{B}$ & $\mathrm{Li}$ & $\mathrm{Na}$ & $\mathrm{Si}$ \\
\hline EA Standard Sample & 17.8772 & 9.5461 & 13.2464 & 3.9202 \\
\hline EA Cited Values & 16.6950 & 9.5650 & 13.3460 & 3.9220 \\
\hline 2HR & 0.9304 & 0.8805 & 0.9127 & 0.4964 \\
\hline 12HR & 1.0372 & 0.8862 & 1.0148 & 0.5249 \\
\hline 28HR & 1.2561 & 1.0853 & 1.2535 & 0.5872 \\
\hline 44HR & 1.1214 & 0.9630 & 1.0704 & 0.4863 \\
\hline 60HR & 1.2145 & 1.1159 & 1.3805 & 0.6002 \\
\hline 72HR & 1.0732 & 0.9732 & 1.2102 & 0.5816 \\
\hline 2HRCCC & 6.1058 & 5.2693 & 2.6169 & 0.9387 \\
\hline 12HRCCC & 44.1089 & 30.9586 & 16.6204 & 4.3939 \\
\hline 28HRCCC & 64.7884 & 26.3512 & 23.9690 & 3.5537 \\
\hline 44HRCCC & 10.9921 & 8.7307 & 5.0010 & 1.0347 \\
\hline 60HRCCC & 49.9757 & 28.8588 & 21.5560 & 3.9051 \\
\hline 72HRCCC & 48.229 & 28.0886 & 19.9305 & 3.8385 \\
\hline
\end{tabular}

X-Ray Diffraction (XRD) analysis was also performed on the six pour samples with and without the CCC thermal treatment. The six quenched samples were essentially amorphous with small amounts of magnetite (crystalline form of iron oxide, $\mathrm{FeO}^{-} \mathrm{Fe}_{2} \mathrm{O}_{3}$ ) and trevorite (nickel-iron oxide, $\mathrm{NiO} \cdot \mathrm{Fe}_{2} \mathrm{O}_{3}$ ). The $\mathrm{CCC}$ thermal treated glasses all had magnetite and trevorite as well as nepheline (see Figure 6). As stated previously, nepheline has a negative impact on glass durability. ${ }^{3}$ The formation of nepheline was due to the higher than targeted sodium levels in the feed. This conclusion is substantiated by the fact that the glass made by SRNL in support of this work prior to the CCIM demonstrations contained the targeted sodium level and passed the PCT even after being subjected to the modified CCC thermal treatment. 


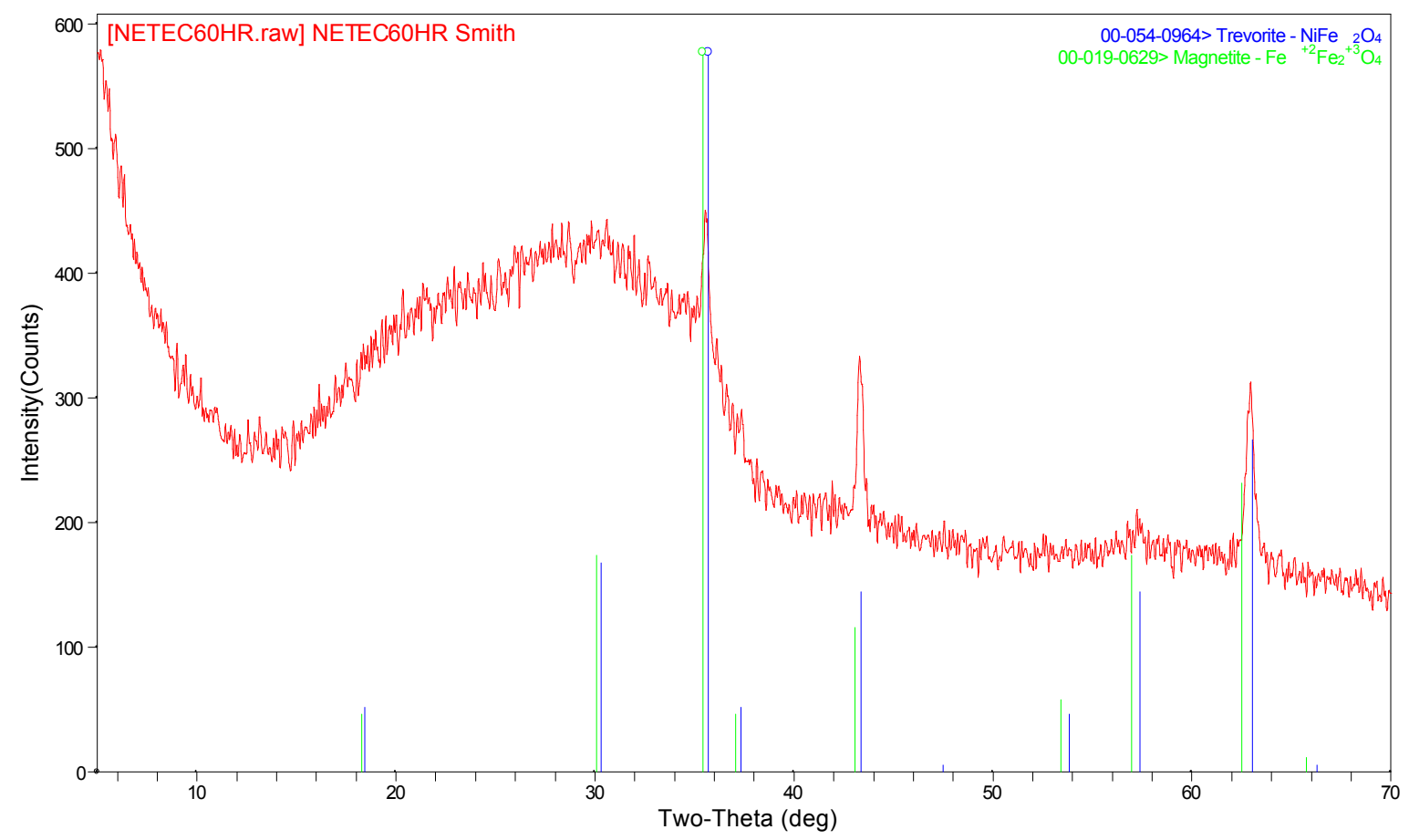

(a) "As is" glass sample

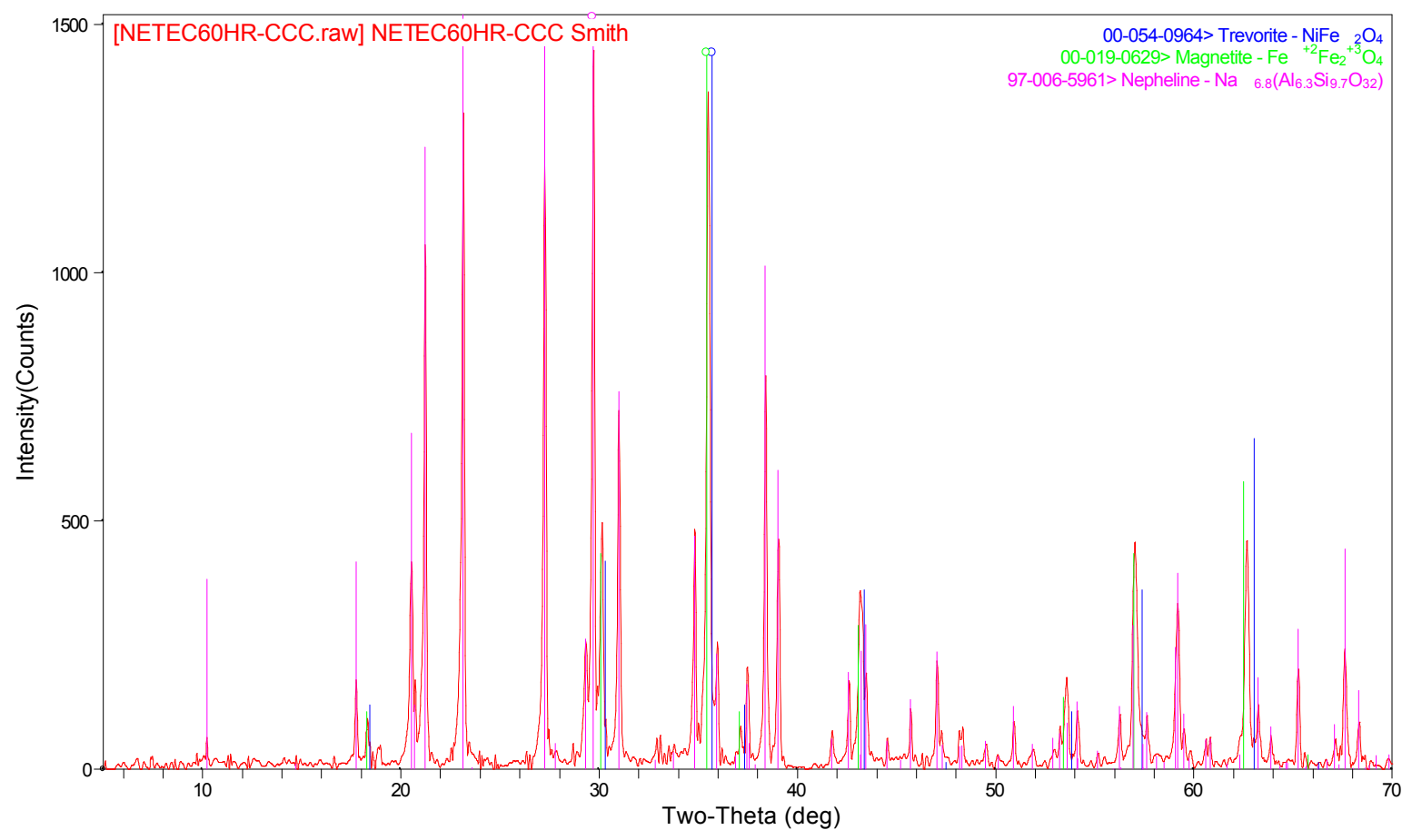

(b) CCC glass sample

Figure 6. Typical XRD Patterns of "as is" and CCC Baseline Demonstration Glass Pour Sample 


\section{Cesium Volatility}

Cesium nitrate was added to the feed in the baseline demonstration to target a concentration of about 0.5 weight percent $\mathrm{Cs}_{2} \mathrm{O}$ in the glass product. Analysis of the six glass pour samples taken indicates an estimated cesium volatility ranging from 34 to 70 percent. In fact, cesium is not just volatilized but entrained as well along with other feed materials. The DWPF design basis cesium carryover to the off-gas system is 10 percent. Therefore, testing to determine those process parameters that may be contributing to these higher than desired cesium carryover rates is needed. In particular, the effects of temperature, bubbling rate, cold cap coverage and waste loading on cesium carryover need to be measured. Testing would involve collection of off-gas particulate samples and subjecting them to the chemical and physical analyses for a full characterization of both volatile and nonvolatile carryovers.

\section{Off-Gas Concentrations}

Off-gas concentrations were measured in both demonstrations. The concentrations of CO (limit $<300 \mathrm{ppm})$ and $\mathrm{NO}_{\mathrm{x}}($ limit $<150 \mathrm{ppm})$ were well below the detection limits for each. The concentration of $\mathrm{SO}_{\mathrm{x}}($ limit $<100 \mathrm{ppm})$ was about 5 ppm.

\section{CONCLUSIONS}

Two 550mm CCIM demonstrations were performed by NETEC for WSRC via a subcontract. The results of the demonstrations indicated that the CCIM appears to be a viable technology for use in the DWPF to increase waste throughput relative to the current DWPF melter. The objectives of the CCIM per the subcontract were all met. The test results indicate that further optimization of glass properties such as liquidus and melt rate can be achieved and verified via additional testing. Below are the major achievements of the demonstrations:

- The ability to process simulated DWPF slurry feed was proven.

- Glass with waste loadings of about 50 percent was produced and subsequent durability tests (PCT) showed that the "as is" glasses were more durable than the EA glass standard by about an order of magnitude. However, four of the six CCC thermal treatment glass samples failed the PCT. The cause of this failure was the formation of nepheline in the CCC thermal treatment glasses as indicated by XRD. Nepheline is known to negatively impact glass durability. The formation of nepheline was attributed to the higher than targeted sodium levels in the feed.

- Based on the demonstration's maximum melt fluxes for $1250^{\circ} \mathrm{C}$ and applying these to a larger CCIM (>1m diameter), much higher waste throughputs than currently demonstrated in the DWPF appear possible.

Additional issues/research needs were identified, some of which are given below.

- Scale-up of melt rates and waste throughputs to full-scale CCIM (larger than $1 \mathrm{~m}$ diameter)

- Processing of the DWPF Chemical Processing Cell flowsheet products in a CCIM

- Off-gas sampling and cesium volatility (impact of bubbling, cold cap coverage, etc.)

- Long term operation of a pilot/full-scale CCIM with DWPF feed

- Assessment of potential off-gas flammability due to lower vapor space temperature of the CCIM than the DWPF Melter 


\section{ACKNOWLEDGEMENTS}

The authors acknowledge the excellent contribution of NETEC for the performance of the two CCIM demonstrations via WSRC subcontract AC59545T.

\section{REFERENCES}

${ }^{1}$ Myung-Jae Song, The Vitrified Solution, Nuclear Engineering International, 22-26 (February 2003).

${ }^{2}$ Myung-Jae Song and San-Woon Shin, Heart of Glass, Nuclear Engineering International, 25-28 (December 2005).

${ }^{3}$ K. M. Fox, et al., Nepheline Formation Study for Sludge Batch 4 (SB4): Phase 3 Experimental Results, WSRC-TR-2006-00093, Revision 0, Washington Savannah River Company, Aiken, South Carolina (2006). 